\title{
PENGEMBANGAN MODEL ASSESSMENT AS LEARNING PEMBELAJARAN AKUNTANSI DI SMK
}

\author{
${ }^{1)}$ Sudiyanto, ${ }^{2}$ Badrun Kartowagiran, ${ }^{3}$ Mubyadi \\ ${ }^{1)}$ Universitas Sebelas Maret, ${ }^{2,3)}$ Universitas Negeri Yogyakarta \\ soeddie.fkipuns@gmail.com; badrunkw@yahoo.com; muhyadi@uny.ac.id
}

\begin{abstract}
Abstrak
Tujuan penelitian ini adalah mengembangkan model assessment as learning (model-AaL) untuk meningkatkan kompetensi siswa pada pembelajaran akuntansi di SMK. Pengembangan model asesmen ini mengadaptasi model pengembangan Hopkin \& Clark, yang terdiri atas dua tahap, yaitu: (1) tahap penelitian, dan (2) tahap pengembangan. Tahap penelitian meliputi: penelitian pendahuluan, studi hasil penelitian, analisis komponen model, penyusunan prototipe model. Tahap pengembangan meliputi: validasi model oleh pakar dan praktisi, melatih guru menggunakan model, uji coba model terbatas dan diperluas disertai evaluasi. Subjek penelitian adalah guru akuntansi dan siswa kelas X kompetensi keahlian akuntansi SMK. Teknik pengumpulan data menggunakan wawancara, kuesioner, pengamatan, dan tes. Teknik analisis data menggunakan pendekatan kualitatif dengan teknik analisis deskriptif dan pendekatan kuantitatif dengan teknik analisis perkembangan (repeated measures analysis) dan paired samples t-test. Hasil penelitian menunjukkan, bahwa: (1) ada enam komponen yang harus ada pada Model-AaL untuk meningkatkan kompetensi akuntansi siswa pada pembelajaran akuntansi di SMK, yaitu: tujuan, tugas terstruktur, asesmen diri, asesmen teman sejawat, pengamatan aktivitas siswa, dan umpan balik; dan (2) model-AaL efektif dapat meningkatkan kompetensi akuntansi siswa pada pembelajaran akuntansi di SMK, dengan nilai $p(\mathrm{Sig})<a(0,05)$.
\end{abstract}

Kata kunci: model-AaL, kompetensi siswa, dan pembelajaran akuntansi.

\section{DEVELOPING A MODEL OF “ASSESSMENT AS LEARNING OF ACCOUNTING LEARNING” AT VOCATIONAL HIGH SCHOOLS}

\author{
${ }^{1)}$ Sudiyanto, ${ }^{2)}$ Badrun Kartowagiran, ${ }^{3)}$ Mubyadi \\ ${ }^{1)}$ Universitas Sebelas Maret, ${ }^{2,3)}$ Universitas Negeri Yogyakarta \\ ${ }^{1)}$ soeddie.fkipuns@gmail.com; ${ }^{2}$ badrunkw@yahoo.com; ${ }^{3)}$ muhyadi@uny.ac.id
}

\begin{abstract}
The objective of this study is to develop model of assessment as learning (model-AaL) to improve the students' competencies in the Accounting learning at Vocational High Schools. It adapted the model claimed by Hopkin \& Clark, consisting of two phases, namely: (1) research and (2) development. The former included preliminary research, study of the research results, analysis of the model components, and the arrangement of model prototype. The latter, comprised model validation by experts and practitioners, teacher training for using the model, limited and extended model experimentations accompanied with evaluation. The subjects of the research were the Accounting teachers and the students in Grade X of the Accounting Expertise Program of Vocational High Schools. The data of the research were gathered through in-depth interview, questionnaire, observation, and test. They were then analyzed by using the qualitative approach with the descriptive analysis technique and the quantitative approach with the analysis techniques of repeated measures analysis and paired samples t-test. The results of the research show that: (1) the model-AaL consists of six components, namely: objective, structured task, self-assessment, peer assessment, observation on student's activities, and feedback; and (2) the model-AaL can effectively improve the students' competencies in Accounting learning at Vocational High Schools, with a value of $\mathrm{p}(\mathrm{Sig})<\alpha(0.05)$.
\end{abstract}

Keywords: model-AaL, students' competencies, accounting learning 


\section{Pendahuluan}

Akuntansi merupakan salah satu mata pelajaran di SMK yang bertujuan untuk mengembangkan kompetensi siswa dalam bidang akuntansi, yang dapat dikembangkan lebih lanjut di pendidikan tinggi dan dunia kerja. Untuk mencapai tujuan pembelajaran tersebut dibutuhkan asesmen yang baik. Asesmen menurut Harlen (2007, p.11) adalah proses pengumpulan, penafsiran dan penggunaan bukti untuk membuat keputusan tentang prestasi siswa dalam pendidikan. Asesmen secara garis besar dapat digunakan: (1) untuk menentukan tingkat pencapaian hasil pembelajaran yang dikenal dengan asesmen sumatif atau assessment of learning (AoL), dan (2) untuk memperbaiki proses pembelajaran yang dikenal dengan asesmen formatif atau assessment for learning (AfL) (Weeden, Winter, and Broadfoot, 2002, p.13; dan Glasson, 2008, p.3). Selanjutnya, asesmen formatif dapat digunakan untuk memperbaiki: (1) proses pembelajaran oleh guru atau assessment for learning, dan (2) proses pembelajaran oleh siswa atau assessment as learning (WNCP, 2006, p.13). Dengan demikian, asesmen dapat digunakan: (1) untuk menentukan tingkat pencapaian hasil pembelajaran atau assessment of learning, (2) untuk memperbaiki proses pembelajaran oleh guru atau assessment for learning, dan (3) untuk memperbaiki proses pembelajaran oleh siswa atau assessment as learning (Earl, 2006, p. 6).

Menurut Earl (2006: 7), asessment of leaning adalah asesmen yang digunakan untuk mengkonfirmasi apa yang siswa ketahui, untuk menunjukkan apakah telah memenuhi standar dan/atau menunjukkan kedudukan siswa dengan siswa lain. Kemudian, assessment for learning adalah asesmen yang rancang untuk memberikan informasi kepada guru untuk memodifikasi kegiatan pembelajarannya, membedakan dan memahami cara siswa melakukan pendekatan belajar. Selanjutnya, assessment as learning adalah bagian dari assessment for learning yang menekankan pada penggunaan asesmen sebagai proses mengembangkan dan mendukung metakognisi siswa, dalam pengertian siswa diberi kesempatan dan dibimbing untuk melakukan pemantauan dan menggunakan hasil pemantuan untuk memperbaiki belajarnya. Penggunaan AoL, AfL dan AaL yang seimbang dapat meningkatkan kualitas proses dan hasil pembelajaran.

Selama ini, penggunaan asesmen dalam pembelajaran di kelas masih belum seimbang. Penggunaan asesmen masih didominasi oleh assessment of learning tanpa diimbangi oleh assessment for learning dan assessment as learning. Earl (2003, p.26) secara rinci mengatakan, bahwa:

At the current juncture, almost the classroom assessment in a traditional environment is summative Assessment of Learning, focused on measuring learning after the fact and used for categorizing students and reporting these judgements to others. A few teachers use Assessment for Learning by building in diagnostic processors - formative assessment and feedback at stages in the program - and giving students second chances to improve their marks (and, it is hoped, their learning). Systematic Assessment as Learning is almost nonexistent.

Volante (2009, p.2) juga mengatakan, bahwa "Only a minority educators were using assessment for and as learning on a consistent basis within their classrooms and schools."

Fenomena tersebut juga terjadi pada pembelajaran akuntansi di SMKN Surakarta. Hasil studi pendahuluan terhadap sembilan guru akuntansi di SMKN Surakarta menunjukkan bahwa: (1) sebagian besar guru memahami asesmen untuk mengukur hasil belajar, (2) hampir semua guru menggunakan tes untuk mengukur hasil belajar, (3) hampir semua guru tidak menggunakan hasil asesmen untuk perbaikan proses pembelajaran guru dan siswa, (4) hampir semua guru tidak melibatkan siswa dalam setiap tahapan proses asesmen, baik dalam menentukan tujuan belajar dan kriteria sukses, penentuan tugas pembelajaran, pemantauan hasil, dan umpan balik untuk perbaikan pembelajaran.

Penggunaan asesmen yang tidak seimbang, tidak mampu memberikan informasi yang dibutuhkan guru dan siswa untuk 
memperbaiki proses pembelajaran (Stiggins \& Chappuis, 2005, p.17; dan Black \& Wiliam, 1998b, p.1). Akibatnya, guru dan siswa tidak dapat memperbaiki proses dan hasil pembelajaran. Untuk itu, perlu penggunaan AfL dan AaL secara efektif dan konsisten dalam pembelajaran di kelas.

Dalam kaitannya dengan penggunaan assessment for learning dan assessment as learning dalam pembelajaran di kelas, Black dan Wiliam (1998a) telah melakukan reviu literatur dan berkesimpulan, bahwa penggunaan assessment as dan for learning (asesmen formatif) yang dirancang dan dilaksanakan dengan baik dapat memperbaiki pembelajaran, yaitu meningkatkan kompetensi siswa, dengan effect sizes antara 0,4 sampai 0,7. Dengan demikian, perlu dikembangkan mo- del assessment for learning dan model assessment as learning yang dapat digunakan guru dalam pembelajaran di kelas.

Dalam kaitannya dengan penggunaan assessment for learning, Mansyur (2009) telah mengembangkan model Assessment for Learning (model-AfL) pada pembelajaran matematika di SMP Negeri Makasar. Hasil penelitian menunjukkan, bahwa penerapan model-AfL dengan menggunakan asesmen diri dapat meningkatkan pemahaman, perilaku, dan kemampuan matematika siswa.

Terdapat 3(tiga) acuan model untuk pengembangan asesmen yang efektif. Tiga model asesmen tersebut dikemukakan oleh Leahy et. al, Haritage, dan McMillan \& Hearn, secara rinci disajikan pada Tabel 1.

Tabel 1. Tiga Acuan Model Pengembangan Asesmen Efektif

\begin{tabular}{|c|c|c|}
\hline Leahy et. al (2005) & Haritage (2010) & McMillan \& Hearn (2008) \\
\hline $\begin{array}{l}\text { Model terdiri atas lima } \\
\text { komponen: } \\
\text { 1. Menjelaskan dan berbagi tujuan } \\
\text { belajar dan kriteria sukses. } \\
\text { 2. Merancang diskusi kelas, } \\
\text { pertanyaan, dan tugas belajar } \\
\text { yang efektif. } \\
\text { 3. Memberikan umpan balik yang } \\
\text { menggerakkan siswa maju } \\
\text { 4. Mengaktifkan siswa sebagai } \\
\text { pemilik belajarnya sendiri } \\
\text { 5. Mengaktifkan siswa sebagai } \\
\text { sumber daya satu sama lain }\end{array}$ & $\begin{array}{l}\text { Model terdiri atas tujuh } \\
\text { komponen: } \\
\text { 1. Menentukan tujuan belajar dan } \\
\text { kriteria sukses } \\
\text { 2. Mendapatkanbukti belajar } \\
\text { 3. Menginterpretasi bukti belajar } \\
\text { 4. Mengidentifikasi kesenjangan } \\
\text { 5. Memberikan umpan balik } \\
\text { 6. Mengadaptasi dan merespon } \\
\text { kebutuhan belajar } \\
\text { 7. Menopang belajar baru dan } \\
\text { menutup kesenjangan }\end{array}$ & $\begin{array}{l}\text { Model terdiri atas tiga komponen: } \\
\text { 1. Menentukan tujuan belajar dan } \\
\text { pembelajaran yang sesuai } \\
\text { 2. Pemantauan diri yang meliputi } \\
\text { kesadaran berfikir atau tindakan } \\
\text { yang harus dilakukan } \\
\text { 3. Penilaian diri yang meliputi } \\
\text { kegiatan untuk mengetahui } \\
\text { kemajuan pencapain tujuan } \\
\text { belajar }\end{array}$ \\
\hline
\end{tabular}

Berdasarkan tiga model asesmen yang ditawarkan tersebut, maka pengembangan model assessment as learning (model-AaL) ini diarahkan kepada model asesmen yang meliputi lima komponen, yaitu: (1) tujuan, yang meliputi tujuan pembelajaran, indikator dan kriteria keberhasilan; (2) tugas pembelajaran terstruktur; (3) asesmen diri, (4) asesmen teman sejawat; dan (5) umpan balik untuk perbaikan pembelajaran. Model asesmen tersebut disajikan pada Gambar 1.

Pada model-AaL ini, guru bertugas membantu siswa: (1) memahami tujuan, (2) mengerjakan tugas terstruktur, (2) melakukan asesmen diri, (3) melakukan asesmen teman sejawat, dan (4) menemukan umpan balik untuk perbaikan pembelajaran.

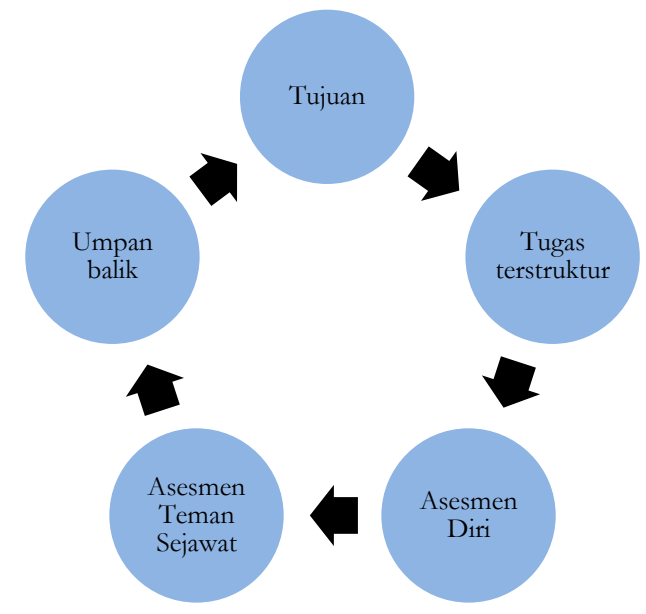

Gambar 1. Model-AaL

Model-AaL dirancang untuk membantu siswa menjadi pembelajar yang lebih 
mandiri dengan cara melibatkan siswa dalam asesmen diri dan asesmen teman sejawat secara terus-menerus untuk mendapatkan umpan balik perbaikan pembelajaran (Arend \& Kilcher, 2010, p.135). Asesmen diri dan asesmen teman sejawat sering dikombinasikan atau dipertimbangkan bersama, karena asesmen teman sejawat dapat membantu asesmen diri. Dengan mengases pekerjaan teman sejawat, siswa memperoleh wawasan tentang kinerjanya sendiri (Bostock, 2010, p.1). Membantu siswa melakukan asesmen diri dan teman sejawat dapat mendorong siswa untuk belajar sepanjang hayat tanpa harus tergantung pada asesmen guru.

Sesuai dengan permasalahan penelitian tersebut, maka yang menjadi tujuan penelitian adalah: (1) untuk mengetahui komponen-komponen yang harus ada pada model-AaL untuk meningkatkan kompetensi akuntansi siswa pada pembelajaran akuntansi di SMK, dan (2) mengetahui keefektifan model-AaL dalam meningkatkan kompetensi akuntansi siswa pada pembelajaran akuntansi di SMK.

\section{Metode Penelitian}

Penelitian ini menggunakan metode penelitian dan pengembangan, dengan mengadaptasi model R, D, \& D dari Hopkins \& Clark (Havelock, 1969), yang terdiri atas dua tahap, yaitu penelitian dan pengembangan. Tahap penelitian, meliputi: penelitian pendahuluan, studi hasil penelitian, analisis komponen model, penyusunan prototype model awal, konsultasi prototype model awal dengan pakar, dan penyusunan prototype model akhir. Tahap pengembangan, meliputi: validasi model oleh pakar dan praktisi, pelatihan guru tentang penggunaan model, uji coba model terbatas dan diperluas disertai evaluasi.

Penelitian dimulai dari bulan Juli sampai dengan Desember 2012 dengan objek penelitian di SMKN 1, SMKN 3, dan SMKN 6 Surakarta. Subjek penelitian adalah guru akuntansi dan siswa kelas X kompetensi keahlian akuntansi. Uji coba terbatas melibatkan 1 orang guru akuntansi dan 40 orang siswa kelas X SMKN 1 Surakarta. Uji coba diperluas melibatkan 3 orang guru akuntansi dan 119 orang siswa kelas X dari SMKN 1, SMKN 3, dan SMKN 6 Surakarta.

\section{Instrumen Penelitian}

Penelitian menggunakan dua instrumen, yaitu instrumen perlakuan dan instrumen pengumpul data. Instrumen perlakuan berkaitan dengan komponen model-AaL yang diujicobakan, yang meliputi: tujuan, tugas terstruktrur, asesmen diri, asesmen teman sejawat, pengamatan aktivitas siswa, dan umpan balik. Instrumen pengumpul data berkaitan dengan kegiatan penelitian, yang meliputi: wawancara penelitian pendahuluan, kuisioner validasi model-AaL oleh pakar dan praktisi, kuisioner keefektifan model-AaL, pengamatan keterlaksanan model-AaL, dan tes kompetensi akuntansi siswa sebelum dan sesudah uji coba modelAaL.

Teknik Analisis Data

Teknik analisis data menggunakan pendekatan kualitatif dengan teknik analisis deskriptif dan pendekatan kuantitatif dengan teknik repeated measures analysis dan paired samples t-test.

\section{Hasil Penelitian dan Pembahasan}

Hasil penelitian dan pembahasan terdiri atas: (1) hasil validasi pakar dan praktisi (2) hasil uji coba terbatas, (3) hasil uji coba diperluas, dan (4) pembahasan hasil penelitian. Masing-masing sebagai berikut.

\section{Hasil Validasi Pakar dan Praktisi}

Sebelum diujicobakan, prototipe dan perangkat model-AaL divalidasi oleh pakar dan praktisi melalui focus group discussion (FGD). Hasil validasi 8 orang pakar (pengukuran, teknologi pembelajaran, dan akuntansi) dan 3 orang praktisi (guru akuntansi SMK) disajikan pada Tabel 2.

Tabel 2 menunjukkan bahwa prototipe model-AaL layak untuk diujicobakan dengan skor rata-rata lebih besar dari 3.25 (amat baik) dan tingkat konsistensi ( $\kappa)$ antar validator sama dengan atau lebih besar 0,70 
(konsisten). Hal ini berarti, bahwa prototipe model-AaL dapat diujicobakan.

Tabel 2. Hasil Validasi Pakar dan Praktisi Prototipe Model-AaL

\begin{tabular}{|c|c|c|c|c|}
\hline No & Materi Validasi & Skor & $\kappa$ & Ket. $\left.{ }^{*}\right)$ \\
\hline 1 & Model dan panduan & 3,64 & 0,88 & Layak \\
\hline 2 & $\begin{array}{l}\text { Lembar pengamatan } \\
\text { keterlaksanaan model }\end{array}$ & 3,68 & 0,83 & Layak \\
\hline 3 & $\begin{array}{l}\text { Angket keefektifan model } \\
\text { untuk guru }\end{array}$ & 3,76 & 0,83 & Layak \\
\hline 4 & $\begin{array}{l}\text { Angket keefektifan model } \\
\text { untuk siswa }\end{array}$ & 3,76 & 0,83 & Layak \\
\hline 5 & $\begin{array}{l}\text { Lembar pengamatan aktivitas } \\
\text { guru }\end{array}$ & 3,75 & 0,76 & Layak \\
\hline 6 & $\begin{array}{l}\text { Rencana pelaksanaan } \\
\text { pembelajaran }\end{array}$ & 3,64 & 0,88 & Layak \\
\hline 7 & Tujuan & 3,75 & 0,70 & Layak \\
\hline 8 & Contoh soal dan penyelesaian & 3,68 & 0,91 & Layak \\
\hline 9 & Soal tugas terstruktur & 3,75 & 0,70 & Layak \\
\hline 10 & $\begin{array}{l}\text { Rubrik pensekoran tugas } \\
\text { terstruktur }\end{array}$ & 3,83 & 0,70 & Layak \\
\hline 11 & lembar asesmen diri & 3,75 & 0,70 & Layak \\
\hline 12 & lembar asesmen teman sejawat & 3,75 & 0,70 & Layak \\
\hline 13 & lembar asesmen guru & 3,75 & 0,70 & Layak \\
\hline 14 & $\begin{array}{l}\text { Lembar pengamatan aktivitas } \\
\text { siswa }\end{array}$ & 3,75 & 0,70 & Layak \\
\hline 15 & Lembar umpan balik & 3,75 & 0,70 & Layak \\
\hline 16 & Soal-soal pre-dan post-test. & 3,68 & 0,83 & Layak \\
\hline
\end{tabular}

Keterangan:

*) Layak digunakan bila Skor $\geq 3,25$ dan $\kappa \geq 0,70$

Hasil uji coba terbatas

Setelah prototipe model-AaL divalidasi oleh pakar dan praktisi dan dinyatakan layak untuk diujicobakan, kemudian diujicobakan dalam lingkup terbatas, yaitu di SMKN 1 Surakarta. Uji coba terbatas tersebut ditujukan untuk mengetahui: (a) hasil penilaian keefektifan model-AaL, (b) hasil pengamatan keterlaksanaan model-AaL, (c) hasil pengamatan aktivitas guru, (d) hasil pengamatan aktivitas siswa, dan (e) hasil uji keefektifan model-AaL secara empiris. Masing-masing adalah berikut.

\section{Hasil Penilaian Keefektifan Model-AaL}

Hasil penilaian keefektifan modelAaL pada uji coba terbatas oleh 3 orang guru dan 6 orang siswa disajikan pada Tabel 3 .
Tabel 3. Hasil Penilaian Keefektifan Model-AaL pada Uji coba Terbatas

\begin{tabular}{lcrrl}
\hline \multirow{2}{*}{$\begin{array}{l}\text { Aspek yang } \\
\text { dinilai }\end{array}$} & \multicolumn{2}{c}{$\begin{array}{c}\text { Rata-rata } \\
\text { Hasil penilaian }\end{array}$} & $\begin{array}{c}\text { Rata- } \\
\text { rata }\end{array}$ & Ket. \\
\cline { 2 - 3 } & Guru & Siswa & & \\
\hline Validitas & 3,22 & 3,94 & 3,58 & Valid \\
Reliabilitas & 3,22 & 3,94 & 3,58 & Reliabel \\
Objektif & 3,08 & 3,88 & 3,48 & Objektif \\
Sistematis & 3,56 & 4,00 & 3,78 & Sistematis \\
Praktis & 3,08 & 3,79 & 3,44 & Praktis \\
Keseluruhan & 3,22 & 3,91 & 3,57 & Efektif \\
\hline
\end{tabular}

Tabel 3 menunjukkan bahwa menurut guru dan siswa, model-AaL tersebut efektif digunakan, dalam arti model-AaL memiliki instrumen yang valid, reliabel, dan objektif dalam memberikan penilaian, serta prosedur yang sistematis dan praktis dalam pelaksanaan. Penilaian guru dan siswa memiliki tingkat konsistensi yang memadai, yaitu $\kappa$ sebesar 0,821 dan 0,842 ( $\kappa>0,70)$.

Hasil Pengamatan Keterlaksanaan Model-AaL

Hasil pengamatan keterlaksanaan model-AaL di kelas pada uji coba terbatas oleh 2 orang pengamat disajikan pada Tabel 4.

Tabel 4. Hasil Pengamatan Keterlaksanaan Model-AaL

\begin{tabular}{cccl}
\hline Pertemuan & $\begin{array}{c}\text { Rata-rata (\%) } \\
\text { keterlaksanaan } \\
\text { model }\end{array}$ & $\kappa$ & Ketegori \\
\hline 1 & 82 & 0,88 & Baik \\
2 & 88 & 0,88 & Baik \\
3 & 97 & 0,94 & Sangat Baik \\
4 & 97 & 0,94 & Sangat Baik \\
Keseluruhan & 91 & 0,93 & Sangat Baik \\
\hline
\end{tabular}

Tabel 4 menunjukkan bahwa menurut pengamat, model-AaL memiliki tingkat keterlaksanaan secara keseluruhan mencapai 91\% (sangat baik). Keterlaksanan modelAaL mengalami kenaikan dari pertemuan pertama $82 \%$ (baik) hingga pertemuan keempat 97\% (sangat baik), dengan tingkat konsistensi pengamat memadai, yaitu $\kappa>$ 0,70 . Hal ini berarti, guru dan siswa menjadi semakin terampil menggunakan model-AaL. 


\section{Hasil Pengamatan Aktivitas Guru}

Hasil pengamatan aktivitas guru dalam penerapan model-AaL di kelas pada uji coba terbatas oleh 2 orang guru pengamat disajikan pada Tabel 5.

Tabel 5. Hasil Pengamatan Aktivitas Guru

\begin{tabular}{cccc}
\hline Pertemuan & $\begin{array}{c}\text { Rata-rata } \\
\text { aktivitas guru }\end{array}$ & $\kappa$ & Kategori \\
\hline 1 & 2,44 & 0,75 & Cukup \\
2 & 2,94 & 0,81 & Baik \\
3 & 3,19 & 0,88 & Baik \\
4 & 3,47 & 0,94 & Sangat Baik \\
Keseluruhan & 3,01 & 0,85 & Baik \\
\hline
\end{tabular}

Tabel 5 menunjukkan bahwa menurut pengamat, aktivitas guru dalam penerapan model-AaL di kelas secara keseluruhan mencapai 3,01 (baik). Aktivitas guru mengalami peningkatan dari pertemuan pertama 2,44 (cukup) hingga pertemuan keempat 3,47 (sangat baik), dengan tingkat konsistensi pengamat memadai, yaitu $\kappa>0,70$ ). Hal ini berarti, guru semakin aktif dalam melaksanakan pembelajaran dengan modelAaL.

\section{Hasil Pengamatan Aktivitas Siswa}

Hasil pengamatan aktivitas siswa dalam penerapan model-AaL di kelas pada uji coba terbatas oleh 2 orang guru pengamat disajikan pada Tabel 6 .

Tabel 6 menunjukkan bahwa menurut pengamat, aktivitas siswa dalam penerapan model-AaL di kelas secara keseluruhan mencapai 3,25 (baik). Aktivitas siswa mengalami peningkatan dari pertemuan pertama 2,60 (baik) hingga pertemuan keempat 3,43 (sangat baik), dengan tingkat konsistensi pengamat memadai, yaitu $\kappa>0.70)$. Hal ini berarti, siswa semakin aktif dalam melaksanakan pembelajaran dengan model-AaL.

Tabel 6. Hasil Pengamatan Aktivitas Siswa

\begin{tabular}{cccl}
\hline Pertemuan & $\begin{array}{c}\text { Rata-rata } \\
\text { aktivitas siswa }\end{array}$ & $\kappa$ & Kategori \\
\hline 1 & 2,60 & 0,73 & Baik \\
2 & 3,30 & 0,82 & Sangat Baik \\
3 & 3,38 & 0,84 & Sangat Baik \\
4 & 3,43 & 0,96 & Sangat Baik \\
Keseluruhan & 3,25 & 0,84 & Baik \\
\hline
\end{tabular}

\section{Hasil Uji Keefektifan Model secara Empiris}

Untuk mengetahui keefektifan model$\mathrm{AaL}$ dalam meningkatkan kompetensi akuntansi siswa pada uji coba terbatas dilakukan uji keefektifan model secara empiris dengan menggunakan Repeated Measures Analysis dan Paired-Samples T Test. Hasil uji kefektifan model tersebut adalah berikut.

\section{Hasil Repeated Measures Analysis}

Repeated Measures Analysis digunakan untuk mengetahui keefektifan model-AaL dalam meningkatkan aktivitas siswa dan kompetensi akuntansi siswa pada setiap pertemuan. Untuk melakukan analisis, perlu uji persyaratan sphericity yang dilakukan dengan Maucbly's Test of Sphericity. Rangkuman hasil perhitungan Mauchly's Test of Sphericity disajikan pada Tabel 7.

Tabel 7. Rangkuman Hasil Perhitungan Mauchly's Test of Sphericity

\begin{tabular}{lccccccccc}
\hline & & & & & & \multicolumn{3}{c}{ Epsilon } \\
\cline { 5 - 9 } Jenis pengamatan & $\begin{array}{c}\text { Mauchly's } \\
\text { Test }\end{array}$ & $\begin{array}{c}\text { Chi- } \\
\text { Square }\end{array}$ & Df & Sig & $\begin{array}{c}\text { Green- } \\
\text { house- }\end{array}$ & $\begin{array}{c}\text { Huynh } \\
\text {-Feldt }\end{array}$ & $\begin{array}{c}\text { Lower- } \\
\text { bound }\end{array}$ \\
\hline Kompetensi Akuntansi (Asesmen Diri) & 0,821 & 86,256 & 1 & 0,061 & 0,872 & 0,765 & 0,250 \\
Kompetensi Akuntansi (Asesmen Teman Sjwt) & 0,984 & 98,231 & 1 & 0,061 & 0,863 & 0,585 & 0,250 \\
Kompetensi akuntansi (Asesmen Guru) & 0,661 & 128,42 & 1 & 0,091 & 0,871 & 0,763 & 0,250 \\
Aktivitas Siswa & 0,781 & 98,326 & 1 & 0,076 & 0,783 & 0,681 & 0,250 \\
\hline
\end{tabular}

Tabel 7 menunjukkan bahwa data kompetensi akuntansi (asesmen diri), (asesmen teman sejawat), (asesmen guru), dan aktivitas siswa telah memenuhi persyaratan sphericity, yaitu nilai $p(\mathrm{Sig})>\alpha(0,05)$. Hal ini berarti, data siap untuk dianalisis. 
Setelah data memenuhi persyarat sphericity, kemudian dilakukan analisis Repeated Measures. Rangkuman hasil perhitungan $\mathrm{R}$ epeated Measures Analysis disajikan pada Tabel 8.

Tabel 8 menunjukkan bahwa nilai $p$ (Sig) untuk kompetensi akuntansi (asesmen diri), (asesmen teman sejawat), (asesmen guru), dan aktivitas siswa masing-masing adalah 0,000 lebih kecil dari nilai signifikansi $\alpha=0,05$ yang dipilih. Hal ini berarti, ada pengaruh positif dan signifikan penerapan model-AaL terhadap peningkatan kompetensi akuntansi (asesmen diri), (asesmen teman sejawat), (asesmen guru), dan aktivitas siswa pada setiap pertemuan.

Tabel 8. Rangkuman Hasil Perhitungan Repeated Measures Analysis

\begin{tabular}{lllllll}
\hline Effect & & Value & F & $\begin{array}{c}\text { Hypo- } \\
\text { thesis df }\end{array}$ & Error df & Sig. \\
\hline \multirow{2}{*}{ Kompetensi Akuntansi (Asesmen Diri) } & Pillai's Trace & 0,682 & $12,178 \mathrm{a}$ & 3,000 & 17,000 & 0,000 \\
& Wilks' Lambda & 0,318 & $12,178 \mathrm{a}$ & 3,000 & 17,000 & 0,000 \\
\multirow{2}{*}{ Kompetensi Akuntansi (Asesmen Teman Sjwt) } & Pillai's Trace & 0,682 & $12,178 \mathrm{a}$ & 3,000 & 17,000 & 0,000 \\
& Wilks' Lambda & 0,318 & $12,178 \mathrm{a}$ & 3,000 & 17,000 & 0,000 \\
Kompetensi akuntansi (Asesmen Guru) & Pillai's Trace & 0,924 & $48,451 \mathrm{a}$ & 4,000 & 16,000 & 0,000 \\
& Wilks' Lambda & 0,076 & $48,451 \mathrm{a}$ & 4,000 & 16,000 & 0,000 \\
Aktivitas Siswa & Pillai's Trace & 0,925 & $49,276 \mathrm{a}$ & 4,000 & 16,000 & 0,000 \\
& Wilks' Lambda & 0,075 & $49,276 \mathrm{a}$ & 4,000 & 16,000 & 0,000 \\
\hline
\end{tabular}

Selanjutnya, untuk mengetahui adanya pengaruh linier perlu diuji dengan tests of within-subjects contrast yang hasilnya dirangkum pada Tabel 9.

Tabel 9 menunjukkan bahwa nilai $p$ (Sig) untuk kompetensi akuntansi (asesmen diri), (asesmen teman sejawat), (asesmen guru), dan aktivitas siswa masing-masing adalah 0,004, 0,003, 0,000, dan 0,000 lebih kecil dari nilai signifikansi $\alpha=0,05$ yang dipilih. Hal ini berarti, ada pengaruh positif yang bersifat linier dari penerapan modelAaL terhadap kompetensi akuntansi dan aktivitas siswa.

Tabel 9. Rangkuman Hasil Perhitungan Tests OfWitbin-Subjects Contrast

\begin{tabular}{lrrrrrr}
\hline Source & Pertemuan & $\begin{array}{c}\text { Type III Sum } \\
\text { of Squares }\end{array}$ & Df & $\begin{array}{c}\text { Mean } \\
\text { Square }\end{array}$ & F & Sig. \\
\hline Kompetensi Akuntansi (Asesmen Diri) & Linear & 10,61 & 1 & 10,61 & 9,75 & 0,004 \\
Kompetensi Akuntansi (Asesmen Teman Sejawat) & Linear & 12,427 & 1 & 12,427 & 18,976 & 0,003 \\
Kompetensi Akuntansi (Asesmen Guru) & Linear & 176,92 & 1 & 176,92 & 99,556 & 0,000 \\
Aktivitas Siswa & Linear & 18,27 & 1 & 18,27 & 100,01 & 0,000 \\
\hline
\end{tabular}

\section{Hasil Paired-Samples T Test}

Analisis Paired-Samples T Test digunakan untuk mengetahui adanya peningkatan kompetensi akuntansi siswa sebelum dan sesudah penerapan model-AaL pada uji coba terbatas. Analisis dilakukan dengan membandingkan kompetensi akuntansi siswa hasil pre- dan post-test.

Untuk melakukan analisis Paired-Samples $T$ Test, perlu uji persyaratan normalitas data pre-test dan post-test dengan menghitung nilai perbandingan statistic dan standard error untuk skewness dan kurtosis. Rangkuman hasil perhitungan normalitas disajikan pada Tabel 10.

Tabel 10. Rangkuman Hasil Perhitungan Normalitas

\begin{tabular}{|c|c|c|c|c|c|}
\hline & Statistic & $\begin{array}{l}\text { Std. } \\
\text { Error }\end{array}$ & $\begin{array}{l}\text { Statistic/ } \\
\text { Std. Error }\end{array}$ & Kriteria & Ket. \\
\hline Skewness & $-0,465$ & 0,374 & $-1,24332$ & $\begin{array}{c}-2,00<\mathrm{x}< \\
2,00\end{array}$ & normal \\
\hline Kurtosis & 0,457 & 0,733 & 0,623465 & $\begin{array}{c}-2,00<\mathrm{x}< \\
2,00 \\
\end{array}$ & normal \\
\hline
\end{tabular}


Tabel 10 menunjukkan bahwa nilai perbandingan statistic dengan standard error untuk skewness dan kurtosis adalah -1.24332 dan 0,623465 yang berada pada kriteria $2.00<\mathrm{x}<2.00$. Hal ini berarti data pre- dan post-test normal.
Setelah memenuhi persyaratan normalitas, selanjutnya dilakukan analisis PairedSamples T Test. Rangkuman hasil perhitungan disajikan pada Tabel 11.

Tabel 11. Rangkuman Hasil Perhitungan Paired-Samples T Test pada Uji Coba Terbatas

\begin{tabular}{|c|c|c|c|c|c|c|c|c|}
\hline \multicolumn{9}{|c|}{ Paired Samples Test } \\
\hline & \multicolumn{5}{|c|}{ Paired Differences } & \multirow{3}{*}{$\mathrm{t}$} & \multirow{3}{*}{$\mathrm{df}$} & \multirow{3}{*}{$\begin{array}{c}\text { Sig. } \\
\text { (2-tailed) }\end{array}$} \\
\hline & \multirow[t]{2}{*}{ Mean } & \multirow[t]{2}{*}{ Std. Dev. } & \multirow{2}{*}{$\begin{array}{l}\text { Std. Error } \\
\text { Mean }\end{array}$} & \multicolumn{2}{|c|}{$\begin{array}{c}95 \% \text { Confidence Interval } \\
\text { of the Difference }\end{array}$} & & & \\
\hline & & & & Lower & Upper & & & \\
\hline $\begin{aligned} \text { Pair } 1 & \text { Nilai post-test - } \\
& \text { Nilai pre-test pada } \\
& \text { uji terbatas }\end{aligned}$ & 3,87750 & 0,23911 & 0,03781 & 3,80103 & 3,95397 & 102.562 & 39 & 0,000 \\
\hline
\end{tabular}

Tabel 11 menunjukkan terdapat beda mean 3,87750 dengan nilai statistik t-hitung sebesar 102,562 dan $p(0,000)<\alpha(0,05)$. Hal ini berarti, ada peningkatan yang signifikan antara kompetensi akuntansi siswa sebelum dan sesudah uji coba model-AaL terbatas.

Berdasarkan hasil uji coba terbatas dapat dinyatakan bahwa model-AaL efektif untuk meningkatkan kompetensi akuntansi siswa.

Hasil uji coba diperluas

Setelah dinyatakan efektif pada uji coba terbatas, model-AaL diujicobakan pada lingkup lebih luas, yaitu: SMKN 1, SMKN 3, dan SMKN 6 Surakarta. Tujuan uji coba diperluas sama dengan tujuan uji coba terbatas, yaitu untuk mengetahui: (a) hasil penilaian keefektifan model-AaL, (b) hasil pengamatan keterlaksanaan modelAaL, (c) hasil pengamatan aktivitas guru, (d) hasil pengamatan aktivitas siswa, dan (e) hasil uji keefektifan model-AaL secara empiris. Masing-masing adalah berikut.

Hasil Penilaian Keefektifan Model-AaL

Hasil penilaian keefektifan modelAaL pada uji coba diperluas oleh 9 orang guru dan 18 orang siswa disajikan pada Tabel 12.

Tabel 12 menunjukkan bahwa menurut guru dan siswa, model-AaL tersebut efektif digunakan, dalam arti model-AaL memiliki instrumen yang valid, reliabel, dan objektif dalam memberikan penilaian, serta prosedur yang sistematis dan praktis dalam pelaksanaan. Penilaian guru dan siswa memiliki tingkat konsistensi yang memadai, yaitu $\kappa$ sebesar 0,797 dan $0,729(\kappa>0,70)$.

Tabel 12. Hasil Penilaian Keefektifan ModelAaL pada Uji coba Diperluas

\begin{tabular}{|c|c|c|c|c|}
\hline \multirow{2}{*}{$\begin{array}{l}\text { Aspek yang } \\
\text { dinilai }\end{array}$} & \multicolumn{2}{|c|}{ Hasil penilaian } & \multirow{2}{*}{$\begin{array}{l}\text { Rata- } \\
\text { rata }\end{array}$} & \multirow{2}{*}{ Keterangan } \\
\hline & Guru & Siswa & & \\
\hline Validitas & 3,63 & 3,69 & 3,66 & Valid \\
\hline Reliabilitas & 3,67 & 3,80 & 3,74 & Reliabel \\
\hline Objektif & 3,64 & 3,67 & 3,66 & Objektif \\
\hline Sistematis & 3,81 & 3,80 & 3,81 & Sistematis \\
\hline Praktis & 3,69 & 3,75 & 3,72 & Praktis \\
\hline Keseluruhan & 3,69 & 3,74 & 3,72 & Efektif \\
\hline
\end{tabular}

Hasil Pengamatan Keterlaksanaan Model-AaL

Hasil pengamatan keterlaksanaan model-AaL di kelas pada uji coba diperluas oleh 2 orang pengamat disajikan pada Tabel 13.

Tabel 13 menunjukkan bahwa menurut pengamat, model-AaL memiliki tingkat keterlaksanaan secara keseluruhan mencapai 93\% (sangat baik). Keterlaksanan model-AaL mengalami kenaikan dari pertemuan pertama $83 \%$ (baik) hingga pertemuan keempat 99\% (sangat baik), dengan tingkat 
konsistensi pengamat yang memadai, yaitu $\kappa>0,70)$. Hal ini berarti, guru dan siswa menjadi semakin terampil menggunakan model-AaL.

Tabel 13. Hasil Pengamatan Keterlaksanaan Model-AaL

\begin{tabular}{|c|c|c|c|c|c|c|c|c|}
\hline \multirow{3}{*}{$\begin{array}{l}\text { Perte- } \\
\text { muan }\end{array}$} & \multicolumn{6}{|c|}{$\begin{array}{c}\text { Rata-rata }(\%) \text { keterlaksanaan } \\
\text { model-AaL di Kelas }\end{array}$} & \multirow{3}{*}{$\begin{array}{l}\text { Rata- } \\
\text { rata }\end{array}$} & \multirow{3}{*}{$\begin{array}{l}\text { Kate- } \\
\text { gori }\end{array}$} \\
\hline & \multicolumn{2}{|c|}{ SMKN 1} & \multicolumn{2}{|c|}{ SMKN 3} & \multicolumn{2}{|c|}{ SMKN 6} & & \\
\hline & $\%$ & $\kappa$ & $\%$ & $\kappa$ & $\%$ & $\kappa$ & & \\
\hline 1 & 92 & 0,82 & 78 & 0,70 & 78 & 0,70 & 83 & Baik \\
\hline 2 & 94 & 0,88 & 89 & 0,76 & 92 & 0,76 & 92 & $\begin{array}{l}\text { Sanga } \\
\text { t Baik }\end{array}$ \\
\hline 3 & 97 & 0,94 & 94 & 0,82 & 97 & 0,76 & 96 & $\begin{array}{l}\text { Sanga } \\
\text { t Baik }\end{array}$ \\
\hline 4 & 100 & 0,94 & 100 & 0,88 & 97 & 0,88 & 99 & $\begin{array}{l}\text { Sanga } \\
\text { t Baik }\end{array}$ \\
\hline $\begin{array}{l}\text { Rata- } \\
\text { rata }\end{array}$ & 96 & 0,90 & 90 & 0,79 & 91 & 0,78 & 93 & $\begin{array}{l}\text { Sanga } \\
\text { t Baik }\end{array}$ \\
\hline
\end{tabular}

\section{Hasil Pengamatan Aktivitas Guru}

Hasil pengamatan aktivitas guru dalam penerapan model-AaL di kelas pada uji coba diperluas oleh 2 orang guru pengamat disajikan pada Tabel 14.

Tabel 14. Hasil Pengamatan Aktivitas Guru

\begin{tabular}{ccccccccccc}
\hline & \multicolumn{1}{c}{ Aktivitas Guru } & & \\
\cline { 2 - 6 } $\begin{array}{c}\text { Perte- } \\
\text { muan }\end{array}$ & \begin{tabular}{c} 
SMKN 1 \\
\cline { 2 - 5 }
\end{tabular} & $\begin{array}{c}\text { Rata- } \\
\text { rata }\end{array}$ & $\kappa$ & $\begin{array}{c}\text { Rata- } \\
\text { rata }\end{array}$ & $\kappa$ & $\begin{array}{c}\text { Rata- } \\
\text { rata }\end{array}$ & $\kappa$ & $\begin{array}{c}\text { Rata- } \\
\text { rata }\end{array}$ & $\begin{array}{l}\text { Kate- } \\
\text { gori }\end{array}$ \\
\hline 1 & 3,26 & 0,82 & 2,47 & 0,76 & 2,59 & 0,82 & 2,77 & Baik \\
2 & 3,47 & 0,88 & 2,74 & 0,82 & 3,03 & 0,82 & 3,08 & Baik \\
3 & 3,53 & 0,88 & 3,24 & 0,88 & 3,41 & 0,88 & 3,39 & $\begin{array}{l}\text { Sangat } \\
\text { Baik }\end{array}$ \\
4 & 3,74 & 0,94 & 3,44 & 0,94 & 3,53 & 0,88 & 3,57 & $\begin{array}{l}\text { Sangat } \\
\text { Baik }\end{array}$ \\
$\begin{array}{c}\text { Rata- } \\
\text { rata }\end{array}$ & 3,50 & 0,88 & 2,97 & 0,85 & 3,14 & 0,85 & 3,20 & Baik \\
\hline
\end{tabular}

Tabel 14 menunjukkan bahwa menurut pengamat, aktivitas guru dalam penerapan model-AaL di kelas secara keseluruhan mencapai 3,20 (baik). Aktivitas guru mengalami peningkatan dari pertemuan pertama 2,77 (baik) hingga pertemuan keempat 3,57 (sangat baik), dengan tingkat konsistensi pengamat memadai, yaitu $\kappa>0,70$ ).
Hal ini berarti, guru semakin aktif dalam melaksanakan pembelajaran dengan modelAaL.

\section{Hasil Pengamatan Aktivitas Siswa}

Hasil pengamatan aktivitas siswa dalam penerapan model-AaL di kelas pada uji coba diperluas oleh 2 orang guru pengamat disajikan pada Tabel 15.

Tabel 15. Hasil Pengamatan Aktivitas Siswa

\begin{tabular}{|c|c|c|c|c|c|c|c|c|}
\hline \multirow{3}{*}{$\begin{array}{l}\text { Perte- } \\
\text { muan }\end{array}$} & \multicolumn{6}{|c|}{ Aktivitas Siswa } & \multirow{3}{*}{$\begin{array}{l}\text { Rata- } \\
\text { rata }\end{array}$} & \multirow{3}{*}{$\begin{array}{l}\text { Kate- } \\
\text { gori }\end{array}$} \\
\hline & \multicolumn{2}{|c|}{ SMKN 1} & \multicolumn{2}{|c|}{ SMKN 3} & \multicolumn{2}{|c|}{ SMKN 6} & & \\
\hline & $\begin{array}{c}\text { Rata- } \\
\text { rata }\end{array}$ & $\kappa$ & $\begin{array}{c}\text { Rata- } \\
\text { rata }\end{array}$ & $\kappa$ & $\begin{array}{c}\text { Rata- } \\
\text { rata }\end{array}$ & $\kappa$ & & \\
\hline 1 & 3,45 & 0,88 & 3,25 & 0,88 & 3,24 & 0,82 & 3,31 & $\begin{array}{l}\text { Sangat } \\
\text { Baik }\end{array}$ \\
\hline 2 & 3,46 & 0,88 & 3,45 & 0,88 & 3,48 & 0,82 & 3,46 & $\begin{array}{l}\text { Sangat } \\
\text { Baik }\end{array}$ \\
\hline 3 & 3,50 & 0,94 & 3,51 & 0,94 & 3,51 & 0,94 & 3,51 & $\begin{array}{l}\text { Sangat } \\
\text { Baik }\end{array}$ \\
\hline 4 & 3,57 & 0,94 & 3,59 & 0,94 & 3,59 & 0,94 & 3,58 & $\begin{array}{l}\text { Sangat } \\
\text { Baik }\end{array}$ \\
\hline $\begin{array}{c}\text { Rata- } \\
\text { rata }\end{array}$ & 3,50 & 0,91 & 3,45 & 0,91 & 3,46 & 0,88 & 3,47 & $\begin{array}{l}\text { Sangat } \\
\text { Baik }\end{array}$ \\
\hline
\end{tabular}

Tabel 15 menunjukkan bahwa menurut pengamat, aktivitas siswa dalam penerapan model-AaL di kelas secara keseluruhan mencapai 3,47 (sangat baik). Aktivitas siswa mengalami peningkatan dari pertemuan pertama 3,31 (sangat baik) hingga pertemuan keempat 3,58 (sangat baik), dengan tingkat konsistensi pengamat memadai, yaitu $\kappa>0,70$. Hal ini berarti, siswa semakin aktif dalam melaksanakan pembelajaran dengan model-AaL.

\section{Hasil Uji Efektivitas Model secara Empiris}

\section{Hasil Repeated Measures Analysis}

Repeated Measures Analysis digunakan untuk mengetahui keefektifan model-AaL dalam meningkatkan aktivitas siswa dan kompetensi akuntansi siswa pada setiap pertemuan. Untuk melakukan analisis, perlu uji persyaratan sphericity yang dilakukan dengan Mauchly's Test of Sphericity. Rangkuman hasil perhitungan disajikan pada Tabel 16. 
Tabel 16. Rangkuman Hasil Perhitungan Mauchly's Test of Sphericity

\begin{tabular}{|c|c|c|c|c|c|c|c|}
\hline \multirow[b]{2}{*}{ Jenis pengamatan } & \multirow[b]{2}{*}{$\begin{array}{l}\text { Mauchly's } \\
\text { Test }\end{array}$} & \multirow[b]{2}{*}{$\begin{array}{l}\text { Chi- } \\
\text { Square }\end{array}$} & \multirow[b]{2}{*}{ Df } & \multirow[b]{2}{*}{ Sig } & \multicolumn{3}{|c|}{ Epsilon } \\
\hline & & & & & $\begin{array}{l}\text { Greenhouse- } \\
\text { Geisser }\end{array}$ & $\begin{array}{l}\text { Huynh- } \\
\text { Feldt }\end{array}$ & $\begin{array}{l}\text { Lower- } \\
\text { bound }\end{array}$ \\
\hline $\begin{array}{l}\text { Kompetensi Akuntansi } \\
\text { (Asesmen Diri) }\end{array}$ & 0,845 & 86,256 & 1 & 0,206 & 0,872 & & 0,250 \\
\hline $\begin{array}{l}\text { Kompetensi Akuntansi } \\
\text { (Asesmen Teman Sejawat) }\end{array}$ & 0,845 & 98,231 & 1 & 0,206 & 0,863 & 0,585 & 0,250 \\
\hline $\begin{array}{l}\text { Kompetensi Akuntansi } \\
\text { (Asesmen Guru) }\end{array}$ & 0,561 & 108,42 & 1 & 0,149 & 0,871 & 0,763 & 0,250 \\
\hline Aktivitas Siswa & 0,981 & 98,326 & 1 & 0,105 & 0,783 & 0,681 & 0,250 \\
\hline
\end{tabular}

Tabel 16 menunjukkan bahwa data kompetensi akuntansi (asesmen diri), (asesmen teman sejawat), (asesmen guru), dan aktivitas siswa telah memenuhi persyaratan sphericity, yaitu nilai $p(\mathrm{Sig})>\alpha(0.05)$. Hal ini berarti, data siap untuk dianalisis.
Setelah data memenuhi persyarat sphericity, kemudian dilakukan analisis Repeated Measures. Rangkuman hasil perhitungan Repeated Measures Analysis disajikan pada Tabel 17.

Tabel 17. Rangkuman Hasil Perhitungan Repeated Measures Analysis

\begin{tabular}{llccccc}
\hline \multirow{2}{*}{ Effect } & & Value & F & $\begin{array}{c}\text { Hypo-thesis } \\
\text { df }\end{array}$ & Error df & Sig. \\
\cline { 3 - 6 } Kompetensi Akuntansi & Pillai's Trace & 0,682 & $12,178^{\mathrm{a}}$ & 3,000 & 17,000 & 0,000 \\
(Asesmen Diri) & Wilks' Lambda & 0,318 & $12,178^{\mathrm{a}}$ & 3,000 & 17,000 & 0,000 \\
Kompetensi Akuntansi & Pillai's Trace & 0,682 & $12,178^{\mathrm{a}}$ & 3,000 & 17,000 & 0,000 \\
(Asesmen Teman Sejawat) & Wilks' Lambda & 0,318 & $12,178^{\mathrm{a}}$ & 3,000 & 17,000 & 0,000 \\
& Pillai's Trace & 0,924 & $48,451^{\mathrm{a}}$ & 4,000 & 16,000 & 0,000 \\
Komp. Akt & Wilks' Lambda & 0,076 & $48,451^{\mathrm{a}}$ & 4,000 & 16,000 & 0,000 \\
(AG) & Pillai's Trace & 0,925 & $49,276^{\mathrm{a}}$ & 4,000 & 16,000 & 0,000 \\
Aktivitas Siswa & Wilks' Lambda & 0,075 & $49,276^{\mathrm{a}}$ & 4,000 & 16,000 & 0,000 \\
\hline
\end{tabular}

Tabel 17 menunjukkan bahwa nilai $p$ (Sig) untuk kompetensi akuntansi (asesmen diri), (asesmen teman sejawat), (asesmen guru), dan aktivitas siswa masing-masing adalah 0,000 lebih kecil dari nilai signifikansi $\alpha=0,05$ yang dipilih. Hal ini berarti, ada pengaruh positif dan signifikan penerapan model-AaL terhadap peningkatan kompetensi akuntansi (asesmen diri), (asesmen teman sejawat), (asesmen guru), dan aktivitas siswa pada setiap pertemuan.

Selanjutnya, untuk mengetahui adanya pengaruh linier perlu diuji dengan tests of within-subjects contrast yang hasilnya dirangkum pada Tabel 18.

Tabel 18 menunjukkan bahwa nilai $p$ (Sig) untuk kompetensi akuntansi (asesmen diri), (asesmen teman sejawat), (asesmen guru), dan aktivitas siswa masing-masing adalah 0,004, 0,000, 0,000, dan 0,000 lebih kecil dari nilai signifikansi $\alpha=0,05$ yang dipilih. Hal ini berarti, ada pengaruh positif yang bersifat linier dari penerapan modelAaL terhadap kompetensi akuntansi dan aktivitas siswa. 
Tabel 18. Rangkuman Hasil Perhitungan Tests Of Within-Subjects Contrast

\begin{tabular}{lcccccc}
\hline \multicolumn{1}{c}{ Source } & Pertemuan & $\begin{array}{c}\text { Type III Sum of } \\
\text { Squares }\end{array}$ & Df & $\begin{array}{c}\text { Mean } \\
\text { Square }\end{array}$ & F & Sig. \\
\hline $\begin{array}{l}\text { Kompetensi Akuntansi } \\
\text { (Asesmen Diri) }\end{array}$ & Linear & 1,361 & 1 & 1,361 & 10,715 & 0,004 \\
$\begin{array}{l}\text { Kompetensi Akuntansi } \\
\text { (Asesmen Teman Sejawat) }\end{array}$ & Linear & 19,215 & 1 & 19,215 & 98,402 & 0,000 \\
$\begin{array}{l}\text { Kompetensi Akuntansi } \\
\text { (Asesmen Guru) }\end{array}$ & Linear & 5076,692 & 1 & 5076,692 & 199,556 & 0,000 \\
Aktivitas Siswa & Linear & 20,327 & 1 & 20,327 & 103,501 & 0,000 \\
\hline
\end{tabular}

\section{Hasil Paired-Samples T Test}

Analisis Paired-Samples T Test digunakan untuk mengetahui adanya peningkatan kompetensi akuntansi siswa sebelum dan sesudah penerapan model-AaL pada uji coba diperluas. Analisis dilakukan dengan membandingkan kompetensi akuntansi siswa dari hasil pre-dan post-test.

Untuk melakukan analisis Paired-Samples $T$ Test, perlu uji persyaratan normalitas data pre-test dan post-test dengan menghitung nilai perbandingan statistic dan standard error untuk skewness dan kurtosis. Rangkuman hasil perhitungan normalitas disajikan pada tabel 19.

Tabel 19 menunjukkan bahwa nilai perbandingan statistic dengan standard error untuk skewness dan kurtosis adalah -1.52703 dan -0.45682 yang berada pada kriteria -2.00 $<\mathrm{x}<2.00$. Hal ini berarti data pre- dan posttest normal.
Tabel 19. Rangkuman Hasil Perhitungan Normalitas

\begin{tabular}{cccccc}
\hline Statistic & $\begin{array}{l}\text { Std. } \\
\text { Error }\end{array}$ & $\begin{array}{c}\text { Statistic/ } \\
\text { Std. Error }\end{array}$ & Kriteria & $\begin{array}{c}\text { Kete- } \\
\text { rangan }\end{array}$ \\
\hline Skewness & $-0,339$ & 0,222 & $-1,52703$ & $\begin{array}{c}-2,00<\mathrm{x} \\
<2,00\end{array}$ & normal \\
Kurtosis & $-0,201$ & 0,440 & $-0,45682$ & $\begin{array}{c}-2,00<\mathrm{x} \\
<2,00\end{array}$ & normal \\
& & & & & \\
\hline
\end{tabular}

Setelah memenuhi persyaratan normalitas, selanjutnya dilakukan analisis PairedSamples T Test. Rangkuman hasil perhitungan disajikan pada Tabel 20.

Tabel 20 menunjukkan terdapat beda mean 3.95210 dengan nilai statistik t-hitung sebesar 678,102 dan $p(0,000)<\alpha(0,05)$. Hal ini berarti, ada peningkatan yang signifikan antara kompetensi akuntansi siswa sebelum dan sesudah uji coba model-AaL diperluas.

Berdasarkan hasil uji coba diperluas dapat dinyatakan bahwa model-AaL efektif meningkatkan kompetensi akuntansi siswa.

Tabel 20. Rangkuman Hasil Perhitungan Paired-Samples T Test pada Uji Coba Diperluas

\begin{tabular}{|c|c|c|c|c|c|c|c|c|}
\hline \multicolumn{9}{|c|}{ Paired Samples Test } \\
\hline & \multicolumn{5}{|c|}{ Paired Differences } & \multirow{3}{*}{$\mathrm{t}$} & \multirow{3}{*}{ df } & \multirow{3}{*}{$\begin{array}{c}\text { Sig. } \\
\text { (2-tailed) }\end{array}$} \\
\hline & \multirow[t]{2}{*}{ Mean } & \multirow[t]{2}{*}{ Std. Dev. } & \multirow{2}{*}{$\begin{array}{l}\text { Std. Error } \\
\text { Mean }\end{array}$} & \multicolumn{2}{|c|}{$\begin{array}{c}95 \% \text { Confidence Interval } \\
\text { of the Difference }\end{array}$} & & & \\
\hline & & & & Lower & Upper & & & \\
\hline $\begin{array}{c}\text { Pair } 1 \text { Nilai post-test - Nilai } \\
\text { pre-test pada uji } \\
\text { diperluas }\end{array}$ & 3,95210 & 0,06358 & 0,00583 & 3,94056 & 3,96364 & 678,102 & 118 & 0,000 \\
\hline
\end{tabular}

Pembahasan Hasil Penelitian

Hasil validasi pakar dan praktisi tentang prototype model-AaL melalui FGD menunjukkan, bahwa enam komponen mo-
del-AaL dan instrumen yang mendukung model-AaL layak untuk diujicobakan. Enam komponnen model-AaL tersebut adalah: (1) tujuan, (2) tugas terstruktur, (3) asesmen diri, 
(4) asesmen teman sejawat, (5) pengamatan aktivitas siswa, dan (6) umpan balik perbaikan pembelajaran.

Hasil uji coba model-AaL, baik secara terbatas di SMKN 1 Surakarta maupun diperluas di SMKN 1, 3, dan 6 Surakarta menunjukkan, bahwa model-AaL efektif meningkatkan kompetensi akuntansi siswa. Hasil penelitian baik dalam uji coba terbatas maupun diperluas tersebut adalah logis, karena model-AaL membantu siswa: (1) memahami tujuan pembelajaran, (2) memahami dan mengerjakan tugas terstruktur, (3) melakukan asesmen diri, (4) melakukan asesmen teman sejawat, dan (5) menemukan umpan balik untuk perbaikan pembelajarannya. Selain itu, hasil penelitian ini juga mendukung hasil penelitian Black dan Wiliam (1998a) yang menyatakan, bahwa penggunaan assessment as dan for learning (asesmen formatif) yang dirancang dan dilaksanakan dengan baik dapat meningkatkan kompetensi siswa, dengan effect sizes antara 0,4 sampai 0,7 . Hasil penelitian ini juga sejalan dengan hasil penelitian pengembangan oleh Mansyur (2009) yang menyatakan penerapan model Assessment for Learning (model-AfL) menggunakan asesmen diri pada pembelajaran matematika di SMP dapat meningkatkan kemampuan matematika siswa.

\section{Simpulan dan Saran}

Berdasarkan hasil penelitian dan pembahasan dapat diambil simpulan dan saran sebagai berikut.

\section{Simpulan}

Ada enam komponen yang harus ada pada model-AaL untuk meningkatkan kompetensi akuntansi siswa pada pembelajaran akuntansi di SMK. Enam komponen tersebut, yaitu: tujuan, tugas terstruktur, asesmen diri, asesmen teman sejawat, pengamatan aktivitas siswa, dan umpan balik. Tujuan meliputi tujuan pembelajaran, indikator, dan kriteria keberhasilan. Tugas terstruktur terdiri atas contoh soal dan penyelesaian, soalsoal tugas terstruktur, dan rubrik asesmen.
Enam komponen tersebut saling berinteraksi dalam proses pembelajaran untuk meningkatkan proses dan hasil pembelajaran akuntansi di SMK.

Model-AaL efektif dapat meningkatkan kompetensi akuntansi siswa pada pembelajaran akuntansi di SMK. Hal ini terbukti dari hasil analisis data repeated measures analysis dan paired samples t-test yang menunjukkan ada pengaruh positif yang signifikan penerapan model-AaL terhadap peningkatan kompetensi akuntansi siswa pada uji coba terbatas dan diperluas, dengan $p(0000)<a$ $(0,05)$.

Saran

Dianjurkan kepada peneliti berikutnya untuk mempertimbangkan penggunaan strategi asesmen diri dengan teknik lain selain modeling using exemplar yang sudah digunakan. Teknik tersebut adalah: questioning skills, selfassessment tools - graphic organizer, reflection as a process for closing the learning gap, response partners, dan digital portfolio.

Dianjurkan kepada guru akuntansi di SMKN Surakarta pada khususnya dan guru akuntansi pada umumnya untuk mempertimbangkan penggunaaan model-AaL pada pembelajaran akuntansi di kelas.

Dianjurkan kepada pengguna untuk mengikuti sintaks yang tersedia, yang terdiri atas tiga tahap, yaitu tahap persiapan, tahap pelaksanaan, dan tahap pelaporan.

\section{Daftar Pustaka}

Arends, R.I., \& Kilcher, A. (2010). Teaching for student learning becoming an accomplished teacher. Madison Avenue, New York: Routledge.

Black, P. \& Wiliam, D. (1998a). Assessment and classroom learning. Assessment in education. 5(1), 7-74.

Black, P. \& Wiliam, D. (1998b). Inside the black box: Raising standards through Classroom Assessment. Phi Delta Kappa, October, 1998. Diambil pada tanggal 25 Maret 2012, dari 
http://academic.sun. ac.za/ mathed/174/ formassess. Pdf.

Bostock, S. (2010). Student peer assessment. Diambil pada tanggal 10 Januari 2012, dari

http://www.keele.ac.uk/depts/aa/ landt/lt/docs/bostock_peer_assessm ent.

Earl, L. (2003). Assessment as learning: Using classroom assessment to maximise student learning. Thousand Oaks, CA, Corwin Press.

Earl, L. (2006). Assessment - a powerful lever for learning. Brock Education. 16(1), 2006.

Glasson, T. (2008). Improving student achieve-ment through assessment for learning. Curriculum \& leadership journal. Volu-me 6 Issue 31. Diambil pada tanggal 15 Pebruari 2012, dari http://cmslive. curriculum.edu.au/leader/vol6 no31, 25022. html?issueID=11603.

Harlen, W. (2007). Assessment of learning. London: A Sage Publications Ltd.

Havelock, R.G. (1969). Planning for innovation: A comparative study of the literature on the dissemination and utilization of scientific knowledge. CRUSK ISR University of Michigan. Michigan: Ann Abror.

Heritage, M. (2007). Formative Assessment: What Do Teachers Need to Know and Do? Phi Delta Kappa 89(02), 140 145. Diambil pada tanggal 10 Januari 2012, dari http://www.pdkmembers.org/ members online/publications/Archi ve/pdf/k0710her.pdf.
Leahy, S., Lyon, C., Thompson, M., et al. (2005). Classroom assessment: Minute-by-minute and day-by-day. Educational Leadership, 63(3), 19-24.

Mansyur. (2009). Pengembangan model assessment for learning pada pembelajaran matematika di SMP. Disertasi doktor, tidak diterbitkan, Universitas Negeri Yogyakarta, Yogyakarta.

McMillan, J. H., \& Hearn, J. (2008). Student self-assessment: The key to stronger student motivation and higher achievement. Educational Horizons 87 (1): 40-49.

Stiggins, R. \& Chappuis, S. (2005). Putting testing in perspective: it's for learning. Diambil pada tanggal 25 Januari 2011, dari http://www.assessmentinst. com/wpcontent/uploads/2009/05/p 110-05 chappuis. pdf

Volante, L. (2009). Assessment of, for, and as learning whithin schools: Implications for transforming classroom practice. Diambil pada tanggal 21 Maret 2010, dari http:// www.icsei2009.org.presentations/Vol ante /Volante.pdf.

Weeden, P., Winter, J., \& Broadfoot, P. (2002). Assessment: What's in it for schools? London: Routledge Falmer.

WNCP. (2006). Rethinking classroom assessment with purpose in mind: Assessment for learning, assessment as learning, assessment of learning. manitoba Education, Citizenship in Publication Data. 